\title{
PENDEKATAN FEMINIS TERHADAP PENAFSIRAN AL-QUR'AN DAN BIBEL
}

\author{
Sabhamis \\ Dosen Fakultas Tarbiyah IAIN Imam Bonjol Padang \\ e-mail: hamisab@yahoo.com
}

\begin{abstract}
The discussion on the feminism approach to interprete Alqur'an and Bible attempts to discover verses that state about gender meanstream. Basically, the verses on gender mention that there are difference between man and woman biologically. This difference aims to make man and woman is able to complete each other so that they are able to live together peacefull and, lovely. However, dignity value between man and woman is the same. The distinction among human beings is seen from the quality of their obedience but it can not be viewed from their gender. Thus, religion rejects all type of gender descriminations.
\end{abstract}

\begin{abstract}
Abstrak: Pembahasan tentang pendekatan feminis terhadap penafsiran al Qur'an dan Bibel berupaya mengungkap teks kitab suci tentang jender. Pada prinsipnya teks kitab suci mengakui ada perbedaan secara biologis di antara perempuan dan laki-laki. Perbedaan itu bukan untuk membeda-bedakan jender, namun dimaksudkan agar perempuan dan laki-laki melengkapi satu dengan yang lain sehingga keduanya dapat hidup bersama dalam damai dan harmoni, saling mengasihi, saling mencintai dan saling menghormati. Nilai kemanusiaan laki-laki dan perempuan adalah sama. Perbedaan di antara manusia hanya terletak pada kualitas taqwanya, bukan pada jenis jendernya. Karena itu, agama mengutuk semua bentuk diskriminasi jender.
\end{abstract}

Kata Kunci: Pendekatan feminis, penafsiran Alqur'an, Penafsiran Bibel

\section{PENDAHULUAN}

Kebudayaan dan tradisi menjadi aspek penting dan sangat berpengaruh dalam kehidupan manusia. Ketika manusia menjalankan perannya, ia tidak bisa dilepaskan dari realitas sosial yang mengitarinya. Budaya patriarki yang selama ini terbangun memberikan ruang yang sempit bagi perempuan dalam menjalankan peran dan keaktifannya dalam dimensi kehidupan. Di sisi lain, hal ini mendatangkan keuntungan bagi kaum adam dan memberikan andil dalam membentuk subordinasi laki-laki terhadap perempuan. Pandangan stereotype dan perlakuan diskriminatif yang diterima oleh kaum perempuan sepanjang perjalanan sejarah manusia merupakan pemahaman yang keliru dalam menerjemahkan dan menafsirkan teks-teks suci. Karena dari sinilah semua persoalan itu muncul, sehingga menjadi polemik yang berkepanjangan.

Berbagai nilai diarahkan dan digunakan untuk mempertahankan status quo pola relasi jender yang berakar dalam masyarakat. Hal ini berlangsung cukup lama sehingga mengendap di bawah alam sadar masyarakat seolah-olah pola relasi jender adalah ketentuan Tuhan. Lebihlebih lagi setelah pola relasi kuasa (power relations) menjadi subsistem dalam masyarakat modern-kapitalis yang kuat, kemudian melahirkan masyarakat new patriarchy. Sema-kin kuat pola relasi kuasa semakin besar pula ketimpangan peran jender di dalam masyarakat karena seseorang akan diukur berdasarkan nilai produktifitasnya. Dengan alasan reproduksi, maka perempuan dianggap tidak semaksimal laki-laki. Perempuan diklaim sebagai komunitas reproduksi, yang lebih tepat mengambil peran domestik, dan laki-laki diklaim sebagai komunitas produktif yang lebih tepat mengambil peran publik. Akibatnya, terciptalah suatu masyarakat yang didominasi oleh laki-laki (male dominated society/al-mujtama' alabawiy). (Nasharudin Umar, 2003: 153). 
Pemikiran stereotip terhadap perempuan dan mengakar pada kultur banyak bangsa yang secara universal telah diterima sebagai kebenaran, menjadi penyebab utama perendahan terhadap komunitas perempuan. Hal ini dikelilingi oleh kisah-kisah dan legenda yang menjadikan perempuan pada posisi yang buruk. Di antara kisahnya seperti yang diuraikan oleh Wahiduddin Khan adalah sebuah cerita dari Yunani kuno yang kemudian beredar di Eropa. Kisah ini tentang perempuan yang pertama diciptakan dari tanah oleh Hephaestus atas kehendak Zeus, raja para dewa. Perempuan ini kemudian diturunkan ke dunia dengan membawa sebuah kotak yang berisi semua jenis kesengsaraan dan kejahatan. Dengan melakukan hal ini, Zeus berniat menghancurkan berkah api yang dicuri Prometheus dari langit untuk dianugrahkan kepada makhluk hidup. Kisah ini menceritakan bahwa sejak kotak itu terbuka, dunia dilanda wabah kejahatan dan kesedihan. Perempuan ini diberi nama Pandora, kata Yunani yang arti asalnya adalah :maha pemberi", tetapi kemudian menjadi sinonim dengan "pemberi semua bentuk kejahatan". (Wahiddun Khan, 2001: 20-21).

Kisah lainnya juga adalah seperti yang tertera dalam Bibel, dalam perjanjian lama, bab kedua Kitab Kejadian ayat 7, 8, 9, 15, 16, 17, 18, 21, 22 dan bab tiga tentang kisah jatuhnya manusia ayat 1 sampai 24 . Secara umum, ayatayat tersebut menceritakan tentang asal mula penciptaan Adam dan Hawa sebagai pendampingnya sampai kutukan Allah terhadap keduanya yang telah melanggar titah Allah untuk tidak memakan buah dari pohon terlarang. Dimana Hawa adalah sebagai orang yang membujuk Adam untuk melanggarnya setelah dikibuli oleh ular. Kisah yang diabadikan dalam Bibel ini meyakinkan para Kristiani bahwa penyebab terusirnya Adam dari suatu kehidupan yang nyaman dan menyenangkan, serta membuahkan cobaan dan kesengsaraan, adalah karena Hawa menyerah pada godaan. Inilah asal-muasal bagaimana manusia pertama harus menanggung beban dosa asal yang menurut ajaran Kristen harus ditanggung oleh seluruh umat manusia. (Wahiddun Khan, 2001: 21-25).

Sementara itu, Kaukab Siddique menguraikankan bahwa kaum perempuan berada pada urutan teratas di antara kaum yang paling tertindas di dunia ini. Penderitaannya semakin bertambah bila kebetulan bagian dari anggota kelas minoritas atau kelas miskin. Keberadaannya selalu dijadikan kambing hitam dari persoalan di dunia ini, bahkan juga tertindas di tengah-tengah komunitas yang religius sebagaimana saat berada di tengah komunitas yang progresif. Atas nama Tuhan, perempuan ditindas, dieksploitasi. Hal ini terlihat pada zaman perbudakan di Amerika, dan pada masa aphartheid di Afrika Selatan, kelompok-kelompok keagamaan dan otoritasotoritasnya telah menyalahgunakan atau memelintir ajaran-ajaran kitab suci untuk membenarkan penindasan terhadap kaum kulit hitam. Begitupun halnya terhadap kaum perempuan yang juga ditindas termasuk juga karena akibat justifikasi oleh otoritas dan lemmbaga keagamaan dengan menyalahgunakan dan menyalahtafsirkan kitab suci. (Kaukab Siddique, 2002)

Deskriminasi terhadap kaum perempuan ini kemudian melahirkan pergerakan-pergerakan perempuan yang dinamakan dengan "feminis". Dalam makalah ini akan dibahas tentang definisi feminis, perkembangan historis pendekatan feminis, perempuan dalam alQur'an dan Bibel serta contoh penafsirannya.

\section{PEMBAHASAN}

\section{Definisi Jender dan Feminis}

Jender berasal dari bahasa Inggris "gender", artinya "jenis kelamin". Dalam Kamus Besar Bahasa Indonesia mengartikannya sama dengan terjemahan dari bahasa Inggris, yaitu "jenis kelamin". (John M. Echol dan Hasan Sadily,1983: 265). Sementara itu perlu dibedakan antara sex (Sex adalah kata yang mengacu kepada fungsi biologis (jenis kelamin) seseorang, apakah secara anatomi ia memiliki jenis kelamin sebagai perempuan atau laki-laki, secara permanen tidak berubah atau sering dikatakan sebagai kodrat atau ketentuan Tuhan. Seks/jenis kelamin bersifat tetap dan merujuk kepada perbedaan yang nyata dari alat kelamin dan perbedaan terkait dengan fungsi kelahiran. Kamla Bhasin, Understanding Gender, terj. Moh. Zaki Hussein, 2001: 4; Elaine Showalter dalam Nasaruddin Umar, 2001: 34.Asriati Jamil 
dan Amany Lubis, 2003:56) dan gender (gender merujuk pada segala atribut dan perilaku yang dibentuk secara kultural yang ada pada laki-laki dan perempuan. Ia bersifat berubah/tidak tetap dari dari waktu ke waktu, dari satu kebudayaan ke kebudayaan lainnya, bahkan dari satu keluarga ke keluarga yang lainnya. Kamla Bhasin, Understanding Gender, h. 4); (Maggie Humm, 2002: 177)). dalam melihat persoalanpersolan perempuan yang berkembang dalam masyarakat. Istilah jender di Indonesia merupakan kosa kata baru yang muncul pada awal tahun 1990-an. Sedangkan di Amerika, istilah "jender" sudah muncul pada era 1960-an, dimana istilah tersebut dijadikan sebagai suatu tuntutan hak, baik kepada negara maupun masyarakat sipil, dalam bentuk perorangan atau golongan, dengan cara sekuler atau agamis, konservatif atau radikal, untuk menyuarakan pentignya eksistensi perempuan. Usaha ini kemudian melahirkan sebuah bentuk kesadaran yang khas, yaitu kesadaran feminis.

H.M. Lips sebagaimana yang dikutip oleh Nasaruddin Umar, mengartikannya sebagai cultural expectations for women and men (harapan-harapan budaya terhadap laki-laki dan perempuan). Kata gender juga diartikan sebagai suatu interpretasi mental dan kultural terhadap perbedaan kelamin antara laki-laki dan perempuan. Jender biasanya digunakan untuk menunjukkan pembagian kerja yang dianggap tepat bagi laki-laki dan perempuan. Jadi, feminis merupakan suatu gerakan kaum perempuan yang menentang segala bentuk diskriminasi dan dehumanisasi terhadapnya karena diciptakan sebagai perempuan.

Zaitunah Subhan menerangkan sekilas tentang beberapa teori jender, yaitu: Pertama, pembentukan sifat maskulin dan feminim adalah karena adanya sosialisasi (nurture) dan kulturisasi. Konsep nurture menganggap perbedaan jender perempuan dan laki-laki disebabkan faktor budaya masyarakat. Kedua, konsep nature yang percaya bahwa perbedaan sifat maskulin dan feminim ada hubungannya dengan pengaruh perbedaan biologis laki-laki dan perempuan. Sintesis dari kedua konsep ini adalah konsep sosio-biologis yang menganggap pembentukan sifat maskulin dan feminim merupakan percampuran dari faktor biologis dan sosiologis. Konsep ini dikenal dengan "biososial", karena melibatkan faktor biologis dan sosial dalam menjelaskan "relasi jender". Namun demikian, menurut Nasarudin Umar, konsep ini disinyalir sebagai konsep untuk melanggengkan sistem patriarkhi. Perbedaan arus pemikiran mengenai konsep nurture dan nature dipengaruhi oleh perkembangan ilmu pengetahuan, terutama ilmu-ilmu sosial, antara lain: pertama, teori struktural fungsional.? Teori ini diterapkan dalam menganalisis kehidupan sosial masyarakat. Pendekatan ini mempunyai warna yang jelas, yaitu mengakui adanya segala keanekaragaman dalam kehidupan sosial. Dalam kondisi seperti itu, dibuatlah suatu sistem yang dilandaskan pada konsensus nilai-nilai agar terjadi adanya inter-relasi yang berbuah harmoni, stabilitas dan keseimbangan (equilibrium). Stabilitas dan keseimbangan tersebut akan tercapai dan sangat ditentukan oleh fungsi dan struktur seseorang dalam sistem. kedua, teori konflik-sosial. Teori ini menjadi alternatif dari aliran struktural-fungsional. Teori ini percaya bahwa setiap masyarakat memiliki kepentingan (interest) dan kekuasaan (power) yang menjadi pusat dari setiap hubungan sosial, termasuk hubungan antara perempuan dan lakilaki. Sifat interest dan power ini akan menyebabkan diferensiasi kekuasaan yang bisa menimbulkan subordinasi yang satu terhadap yang lainnya. Maka dengan terjadinya konflik, perubahan posisi dan hubungan bisa terwujud.

2. Perkembangan
Pendekatan Feminisme
Zaitunah Subhan mengklasifikasikan gerakan feminisme menjadi lima kelompok, yakni sebagai berikut:

1. Gerakan Feminisme Liberal

Gerakan ini berkembang di Barat pada abad ke-18 bersamaan dengan populernya arus pemikiran baru "zaman pencerahan" (aufklarung/renaissance). Gerakan ini meyakini bahwa setiap orang yang diciptakan dengan hak-hak yang sama, maka diperlukan: Pertama, adanya gerakan penyadaran terhadap perempuan yang dibekali dengan ilmu pengetahuan agar mampu berkompetisi di tengah masyarakat. Kedua, menuntut pembaharuan hu- 
kum yang diskriminatif terhadap perempuan. Pembaharuan hukum yang dimaksud salah satunya adalah perubahan segala undang-undang dan hukum yang dianggap dapat melestarikan institusi keluarga yang bersifat patriakal. Menurut para feminis liberal, banyak perempuan terhambat "kemajuannya" di dunia publik karena mempunyai anak, oleh karena itu perlu ditunjang pemberian hak reproduksi.

2. Gerakan Feminisme Radikal

Gerakan ini bertumpu pada konsep biological essentialism (perbedaan esensi biologis). Pendekatan yang digunakan aliran ini adalah paradigma bahwa apa saja yang berhubungan dengan makhluk lakilaki dianggap negatif dan menindas. Perbedaan biologis terkait dengan peran keibuan dan kehamilan yang selalu menjadi peran perempuan. Maka, melalui manifesto yang mereka kemukakan dalam Notes from the Second Sex (1970), aliran ini menolak adanya institusi keluarga, baik secara teoritis maupun praktis. Kelompok ini berupaya memutuskan hubungan dengan laki-laki dan membentuk kelompok lesbi. Seangkan kepuasan seksual dari laki-laki (menurut aliran ini) hanyalah masalah psikologis, artinya dengan melakukan berbagai latihan dan pembiasaan, kehangatan dan kemesraan, kepuasaan seksual dapat terpenuhi dari sesama perempuan.

Gerakan ini mengedepankan relasi seksual sebagai isu mendasar dan seksualitas juga dikaitkan dengan persoalan politik. Menurut mereka, politik merupakan hubungan yang didasarkan pada sistem patriarkhi. Sehingga gerakan ini berjuang untuk melenyapkan struktur patriarkhi yang ada di masyarakat.

\section{Gerakan Feminisme Marxis}

Yaitu gerakan yang didasarkan pada teori Marxis, dimana salah satu tokohnya adalah Clara Zetkin (1857-1933). Gerakan ini memperjuangkan sistem sosial ekonomi yang eksploitatif terhadap perempuan, sebagaimana revlusi proletar yang berhasil meruntuhkan sistem kelas, dimana penindasan terhadap perempuan juga akan lenyap. Maka, isu perempuan menurut aliran ini harus diletakkan dalam kerangka kritik atas kapitalisme.

Menurut gerakan ini, sebelum kapitalisme berkembang, keluarga adalah kesatuan produksi. Semua kebutuhan manusia untuk mempertahankan hidupnya dilakukan oleh semua anggota keluarga termasuk perempuan. Namun, setelah kapitalisme industri berkembang keluarga tidak lagi menjadi kesatuan produksi. Kegiatan produksi barang-barang kebutuhan manusia telah beralih dari rumah ke pabrik. Perempuan tidak lagi ikut dalam kegiatan produksi. Kemudian terjadi pembagian kerja secara seksual, dimana laki-laki bekerja di sektor publik yang bersifat produktif dan bernilai ekonomis, sedangkan perempuan bekerja di sektor domestik yang tidak produktif dan tidak bernilai ekonomis. Aliran ini juga menolak anggapan tradisional dan para teolog bahwa laki-laki lebih unggul dari perempuan karena faktor biologis dan latar belakang sejarah.

4. Gerakan Feminisme Sosialis

Gerakan ini merupakan sintesa dari gerakan feminisme Marxis dan radikal yang menganggap bahwa perempuan tereksploitasi oleh dua hal, yaitu sistem patriarkhi dan kapitalis. Asumsi yang digunakan adalah kapitalisme bukan satusatunya penyebab utama keterbelakangan perempuan. Walaupun perempuan sudah mandiri di negara-negara kapitalis, namun mereka masih hidup dalam penindasan dan terkungkung oleh sistem patriarkhi. Gerakan ini menolak marxisme klasik dan menganggap bahwa eksploitasi ekonomi lebih esensial daripada penindasan jender. Solusi yang diajukan oleh feminis sosialis adalah dengan mengupayakan pemberdayaan ekonomi dan politik kaum perempuan.

Gerakan ini juga membuat propaganda kehidupan lesbian sebagai kehidupan seks alternatif. Para feminis tersebut 
berusaha menyadarkan kaum perempuan bahwa institusi keluarga dan lembaga perkawinan merupakan penghambat besar yang harus dimus-nahkan dalam upaya meraih kebebasan.

5. Gerakan ekofeminis.

Gerakan ini muncul dari diskusi feminis pada tahun 1980 yang lebih memfokuskan pada analisa kualitas feminin, membuat kritikan tajam pada feminisme modern (liberal, radikal, marxis dan sosialis), dan percaya bahwa perbedaan jender bukan semata-mata konstruksi sosial budaya, namun juga faktor instrinsik. Teori feminisme modern berasumsi bahwa individu adlah makhluk otonom yang lepas dari pengaruh lingkungannya dan berhak menentukan hidupnya sendiri. Sedangkan teori ekofeminisme lebih cenderung melihat individu secara lebih komprehensif yaitu makhluk yang terikat dan berinteraksi dengan lingkungannya. Dari sini terlihat adanya pergeseran ideologi dari konflik sosial menuju paradigma strukturalfungsional yang memberikan tempat terhadap adanya saling ketergantungan antara individu dalam sebuah sistem.

Gerakan ekofeminis ini muncul bersamaan dengan perkembangan baru dalam filsafat etika yang tidak puas akan arah perkembangan ekologi dunia yang semakin bobrok. Pra penganut ekofeminisme merasa dikhianati dengan janji dari kalangan feminisme modern yang mengemukakan bahwa bila kaum perempuan masuk ke dalam dunia maskulin, maka kaum perempuan dapat mengubah dunia menjadi lebih feminin dan damai. Namun pada kenyataannya, peradaban dunia yang modern semakin dominan diwarnai oleh kualitas maskulin. Inilah kualitas penonjolan diri untuk memperebutkan materi dan statusyang memang merupakan komoditas terbatas dan harus diperebutkan. Akibatnya, yang sering terlihat adalah kompetisi, self centered, dominasi dan eksploitasi.
Semakin rusaknya alam, meningkatnya kriminalitas, menurunnya solidaritas sosial, semakin banyaknya perempuan yang menelantarkan anaknya adalah contoh nyata dari menurunnya kualitas feminin.

Sementara itu Sue Morgan memaparkan bahwa perempuan diposisikan dalam suatu periode sejarah yang menentang pembatasanpembatasan yang dikenakan oleh otoritas keagamaan kepadanya. Asal usul bentuk yang dapat dikenal dari feminisme religius AngloAmerican yang teroganisir muncul pada abad XIX dan didominasi oleh dua isu utama, perbedaan tentang persamaan akses jabatan pendeta (ministry) dan kristisme Injil. (Sue Morgan, Femins Approach, 79)

Kemajuan serentak oleh dari gerakan perempuan sekuler yang menyebabkan meningkatnya kesempatan dalam pendidikan dan pekerjaan, memberikan feminis religius Inggris dan Amerika satu bahasa untuk mengkritik sikap-sikap ambivalen itu. Dengan menolak untuk terlibat dalam posisi pertanggungjawaban dan pembuatan keputusan dalam pemerintahan gerejawi, pendeta perempuan secara langsung naik pada otoritas yanag lebih tinggi dalam studi mereka terhadap Bible. Oleh feminis, mandat ketuhanan secara jelas dibedakan dari interpretasi laki-laki yang dapat keliru sebagaimana mereka menegaskan dispensasi kharismatik untuk jabatan khotbah (preaching office), prinsip Injil tentang egalitarianisme spritual dan watak universal kebangkitan Yesus. Ketika Antoinette Brown ditahbiskan dalam jemaah gereja New York tahun 1853 misalnya, ini dilakukan di bawah teks yang diambil dari Gal 3: 28: dalam Yesus tidak ada laki-laki dan tidak ada perempuan". Demikian juga ketika Richard Allen menolak untuk mentahbiskan Jarena Lee ke dalam gereja Epikostal Metodist Afrika, Lee mencatat dalam biografi spritualnya" dan mengapa dianggap tidak mungkin, bid'ah, dan tidak layak bagi permpuan untuk berkhotbah? Lihatlah sang penyelamat mati demi perempuan dan laki-laki! Tidakkah dia sang penyelamat yang utuh, dari pada menyelamatkan satu di antara keduanya". Demikian pun perdebatan yang sama seperti yang ditunjukkan oleh suatu penelitian 
komparatif Jacqueline Field Bibb tentang methodisme, Anglicanisme, dan Katolik Roma. (Sue Morgan, Femins Approach, 66)

Ketika kepemimpinan yang sah tidak datang, perempuan mencari jalan alternatif untuk memperbesar klaim mereka terhadap ekspresi diri spritual. Sebagian terus berdakwah tanpa persetujuan umat. Yang paling patut dicatat pada periode itu adalah Jarena Lee dan Amanda Berry Smith, melakukan perjalanan kependetaan keliling yang sangat melelahkan tanpa dukungan formal dan hanya sedikit penjagaan secara fisik. Pola serupa ditunjukkan dalam kajian-kajian perempuan revivalis Inggris dalam metodis sektarian kelas pekerja. Perempuan lain yang mengangkat diri mereka sendiri seagai pemimpin-pemimpin gerakan keagamaan baru, dikuatkan oleh gelombang revivalis pada abad setelahnya. Daya dorong kekuatan suci Phoebe Palmer telah terbukti dan pemgaruh Catherine Booth dalam meletakkan kekuatan keselamatan (salvation army) dipinggir (marginal) dari akses perempuan terhadap kependetaan. (Sue Morgan, Femins Approach, 67)

Selanjutnya sekte yang dibangun perempuan, Shakers didirikan oleh Ibu Ann Lee atau gerakan Kristen Mary Baker Edy. Komitmen kedua komunitas tersebut terhadap kesamaan spritual secara penuh bagi perempuan digambarkan dalam pembelaan mereka yang luar biasa atas gambaran mental (imagery) pertempuran dalam pewahyuan. (Sue Morgan, Femins Approach, 67)

Kuatnya hubungan ideologis antara gerakan perempuan dan anti perbudakan atau penghapusan perbudakan, suatu keadaan yang diisi oleh semangat Evangelis untuk melakukan reformasi, menyebabkan agama menjadi faktor yang kuat dalam membentuk dan mengarahkan feminisme di Amerika. Aliansi instrintik antara keagamaan perempuan dan kualitas politis digambarkan dalam dominasi numerical perempuan Quaker (anggota perkumpulan Kristen yang anti perang dan anti sumpah) di Senecca yang mengasilkan konvensi 1884 dan resolusi final deklarasi hak-hak perempuan yang dibaca dalam pertemuan oleh pendeta Quaker,Luccretia Mott.
Keterlibatan feminis dengan agama di abad XIX merupakan suatu yang rumit dan berbelit, namun mengilhami baik tanggapan yang konservatif maupun radikal. Feminisme Evangelis mendasarkan seruannya pada perluasan para kewarganegaraan perempuan yang mendasarkan pada definisi tradisional feminis, memuji bakat permpuan terhadap pengasuhan dan kecendrungannya untuk menafikan dirinya demi kepentingan orang lain sebagai kualitas moral yang patut dicontoh.

Di sisi lain, feminis liberal menentang ideal-ideal Injil tentang subordinasi dan domentifikasi perempuan, menuntut kesetaraan politik dan sosial sekalipun dengan perbedaan seks sebagai hak yang diberikan Tuhan. Pada tahun 1890, teorisi feminis Liberal Amerika, (Sue Morgan, Feminis Approach, 66) Elizabeth Cady Stanton dan Matilda Joslyn Gage, (Sue Morgan, Feminis Approach, 68) menghasilkan dua dari kritik agama biblical (Injil) yang paling tajam selama abad ini (dasar-dasar keinjilan dalam agama institusional adalah penyebab utama inferioritas perempuan). Gage menampakkan kesadaran yang tajam dari peran gereja dalam mendukung patriarki,dan menyatakan bahwa sejarah Kristiani sematamata dibangun berdasarkan kepada ketidaksetaraan jenis kelamin dan ketidakberdayaan perempuan meliputi banyak hal. Hal ini tidak berarti Gage anti religius, terlihat dalam pernyatanna bahwa perempuan juga diciptakan dalam image ketuhanan dan oleh karena itu, merencanakan representasi simbolik yang sama, yang lebih dulu menjadi perdebatan feminis religius kontemporer yang significan hampir selama 10 tahun.

Berlawanan dari hal itu, Frances Power Cobbe, keyakinan Stanton lebih condong kepada keyakinan Unitarian dalam suatu kebaikan rasional. Bersama dengan Senecca Falls meyakini bahwa kemajuan sosial dan politik tidak akan pernah terjadi tanpa terkait dengan pembebasan perempuan dari dominasi image skriptual yang menindas. Dengan menggunakan pandangan-pandangan kontemporer dari Darwin dan kritisisme Injil yang memungkinkan untuk membuat interpretasi yang lebih liberal terhadap Injil, Stanton dan suatu tim 30 penerjemah termasuk Matilda 
Gage mengumpulkan komentar kritis terhadap seluruh bagian Injil yang terkait dengan perempuan.

The Woman's Bible yang dipublikasikan tahun 1895 dan 1898 tidak berusaha menolak Injil sekaligus, tetapi membongkar watak androsentrisme atau keterpusatan pada laki-laki dari tafsir skriptual yang ada.

Sarjana-sarjana perempuan kontemporer juga menerima dorongan ideologis yang sangat besar dari persoalan-persoalan yang dimunculkan oleh gelombang feminisme kedua tahun 1960 dan 1970. Seperti pendekatan teoretis pada pendahulunya, proyek kritis fenimisme kontemporer dimulai dengan pembahasan yang komprehensif terhadap misoginitas agama Barat yang membuka kedok penyebaran inferioritas permpuan dalam setiap periode sejarah Yahudi dan Kristen. Dari perintah Bibel terhadap pembungkaman perempuan, hingga tulisan-tulisan klasik Tertullian, Jerome, Augustine, dan Aquinas, "hubungan yang berbahaya" antara agama dan jenis kelamin bukanlah hal yang peripheral dan kebetulan, melainkan tema sentral yang mendominasi.

Salah satu teori eksplanatoris yang paling berpengaruh adalah yang dikemukakan oleh Rosemary Radford Reuther (Rosemary Radford Reuthwr dalam Sue Morgan, 72-73) yang menyatakan bahwa pencemaran keagamaan terhadap perempuan bergantung pada serangkian kesalahan teologis dan dualisme antropologis. Teolog-teolog Kristen awal yang mendukung antropologi Aristotelian yang cacat dimana perempuan dianggap sebagai bentuk laki-laki yang hina akal, fisik, dan moralitasnya dianggap tidak sempurna. Dengan mengambil pandangan dari dunia hierarkis dari filsafat Yunani klasik, menurut Reuther agama Kristen menambah kesalahpahaman antropologis ini menjadi lebih besar, mempolarisasikan wilayah surga dan bumi, jiwa dan fisik, kultural dan natural, laki-laki dan perempuan, akal dan perasaan, dalam sebuah model dominasi dan penundukan. Bersesuaian dengan pemikiran patriarkis ini budaya laki-laki mencapai arogansi dengan merebut unsur positif untuk dirinya sendiri, sebagai sisi superior dari dualisme. Perempuan, telah dihubungkan sebagai penanggungjawab utama dosa, melaui identifikasinya dengan simbol Hawa, yang konsekuensinya diidentifikasikan dengan sifat yang lebih rendah, fisikal, wilayah materiil. Hanya dengan membujang perempuan dapat melampaui keterkaitannya dengan bagian kemanusaiaannya yang telah hancur, meraih kualitas spritual yang terkait dengan laki-laki. Perilaku ini didasarkan pada pemfitnahan seksualitas perempuan yang ditunjukkan dalam banyaknya tabu-tabu keagamaan di sekitar menstruasi dan melahirkan anak. Representasi negatif perempuan sebagai yang jahat, penggoda, berbahaya dan diimbangi dengan ideal-ideal tentang keperawanan dan keibuan yang diproyeksikan laki-laki (ditunjukkan dengan perawan suci) serta agama Kristen bertanggung jawab atas perannya dalam membantu perkembangan image yang sangat ambigu tentang feminitas.

Salah satu aspek pendekatan feminis yang paling berbeda dan produktif adalah kemampuannya yang konsisten untuk mencakup spektrum respon yang luas. Sekitar tahun 1970, penyingkapan rahasia patriarki keagamaan telah membangkitkan berbagai macam strategi yang bertalian dengan feminisme dan agama. Pada awalnya, ini dikategorikan pada dikotomi reformis/radikal. Dalam Woman Spirit Rising: A Feminist Reader in Religion dikemukakan suatu penelitian yang bermanfaat tentang ketegangan yang sedang berlangsung begitu jauh dalam teologi feminis, didasrkan pada sikap yang berbeda-beda terhadap pengalaman perempuan, signifikan sejarah masa lampau dan inti simbolsimbol keagamaan. Ketegangan itu menggambarkan pembedaan klasik dalam teori feminis pada umumnya apakah bertujuan "kesetaraan atau pembedaa". Feminis reformis yang dalam mengkonstruksi turut menerima tradisi keagamaan, cenderung memfokuskan pada kesetaraan laki-laki perempuan dalam kerangka kerja pembebasan perempuan yang lebih luas. Feminis radikal menekankan pembedaan esensial antara jenis kelamin, menyerukan pada penemuan kembali prinsip feminim sebagai akhir dari dominasi patriarkal.

Reuther mendefinisikan patriarki sebagai rangkaian yang terbangun secara historis, struktur sosial penuh dosa yang terbuka untuk 
direvisi melalui perjuangan politik feminis. Sementara itu, Daly mengemukakan kejahatan patriarki lebih sebagai suatu kondisi kesadaran palsu di mana di dalamnya perempuan ditundukkan dalam alienasi yang pedih dengan menjadikannya kasta yang terus menerus sebagai yang lain. Dalam Beyond God the Father dikemukakan kritik yang sangat telak terhadap agama Kristen sebagai agama yang memberhalakan laki-laki, dengan menegaskan bahwa inti simbolisme Tuhan ayah, dan Kristus yang laki-laki memperkuat otoritas laki-laki dalam masyarakat dan menghadirkan hambatan besar bagi berkembangnya penghargaan terhadap spritualitas perempuan. Sementara Reuther mencari jalan pembebasan yang positif dalam agama Bibel yang memungkinkan untuk membangun kesadaran teologi feminin secara kritis, pendekatan Daly mengemukakan bahwa satu-satunya pilihan yang ada adalah dengan melakukan perombakan simbolisme dalam suatu pembalikan dramatis atau meninggalkan semuanya. Dalam buku selanjutnya, Christ dan Plaskow harus merevisi polarisasi pendekatan reformis/radikal demgan menyatakan bahwa meningkatnya ketumpangtindihan dan kompleksitas teoretis, lebih baik direfleksikan dalam suatu model pendekatan feminin terhadap agama yang bersifat kesinambungan. Meski banyak kemungkinan untuk mengklarifikasi kesarjanaan feminim, namun "keputusan untuk berjuan atau tidak dalam kaitan dengan Yahudi dan Kristen atau memfokuskan pada jalan penolong alternatif bagi spritualitas perempuan", tetap terbukti sebagai metode yang bernilai untuk memahami perbedaan-perbedaan ideologis dan institusional dalam feminisme religius.

3. Perempuan dalam al-Qur'an dan Bibel serta Contoh Penafsirannya.

Berbicara mengenai wanita dan perempuan, maka kita akan diingatkan dengan penyebutan "perempuan". Wanita dan perempuan dalam al-Quran disebut dengan kosa kata yang beragam, diantaranya: mar'ah, imra'ah, nisa', atau niswah, dan unsa. Dalam bahasa Arab, kata-kata tersebut memiliki makna yang berbeda. Kata al-nisa' adalah bentuk jamak dari kata al-mar'ah yang berarti perempuan yang sudah matang atau dewasa.--Lisan al-'Arab, Jilid XV, h. 321, bandingkan dengan Louis Makluf dalam Al-Munjid fi alLughah wa al-I'lam, yang menyatakan bahwa akar kata nisa' adalah nasiya yang berarti lupa disebabkan karena kelemahan akal, bisa juga bermakna jinak dan tenang hatinya, sedangkan kata unsa artinya lemah lembut dan halus perkataannya. Berbeda juga dengan Jurjan Mas'ud al-Ra'idu dalam Mu'jam Lughawy al'Asry yang menyatakan bahwa (dilihat dari filologi Arab) bahwa kata nisa' ini berarti anisa yaitu menghibur. Louis Makluf, Al-Munjid $f i$ al-Lughah wa al-I'lam, (Beirut: Dar al-Masyriq, 1986), h. 807; Jurjan Mas'ud al-Ra'idu, Mu'jam Lughawy al-'Asry, (Beirut: Dar al-Ilm, 1981), Jilid III, h. 1353; Zaitunah Subhan, Tafsir Kebencian: Studi Bias Gender dalam Tafsir Qur'an, 18.--- Lalu, kata unsa dalam hal ini berarti lemah, lunak dan lembek, lawan dari kata kuat, keras yaitu zakarun (pria) yang berarti tajam, kuat ingatan, cerdas. (Elias Anthon Elias, 1977: 232; Zaitunah Subhan, 26) Kata inasa adalah bentuk jamak dari kata unsa yang makna asalnya adalah wanita. Lalu, kita diajak melihat kata inasa pada surat al-Nisa/4: 117, yang diartikan dengan berhala. Patungpatung Arab jahiliah biasa diberi nama-nama wanita seperti Lata, Uzza, dan Manat. Bahkan, kata tersebut juga dapat dimaknai dengan orangorang mati yang disebabkan kelemahannya seperti wanita.

Perbedaan kata yang merujuk kepada wanita tersebut membawa perbedaan dalam penggunaannya dalam al-Quran. Kata imra'ah digunakan untuk mengungkapkan sosok pribadi (karakter), kata nisa' digunakan untuk menyebut sifat (kondisi) umum wanita atau aturan untuk wanita, dan kata unsa digunakan untuk menyebut jenis kelamin wanita dan juga hewan (betina). Dalam al-Qur'an penggunaan kata nisa' berpasangan dengan rijal dan unsa dengan zakar. Bandingkan dengan analisa mengenai topik yang sama yang dilakukan oleh Nasaruddin Umar dalam Argumen Kesetaraan Jender; Perspektif al-Quran, kata al-nisa' adalah bentuk jamak dari kata al-mar'ah yang berarti perempuan yang sudah matang atau dewasa. Berbeda dengan kata al-unsa yang berarti jenis kelamin perempuan secara umum, dari yang 
masih bayi sampai yang sudah berusia lanjut. Kata al-nisa' berarti jender perempuan, dan sepadan dengan kata al-rajul yang berarti jender laki-laki. Kata tersebut juga berarti istri/zawj. (Nasaruddin Umar, 2001: 159-179).

Diskursus kesetaran jender ini sebenarnya telah ada sejak zaman Rasulullah saw hidup, hanya saja tidak terlalu diperdebatkan. Pada waktu itu, Ummu Salamah pernah mempertanyakan kepada Rasulullah saw tentang naskah Qur'an yang kurang memberi tempat kepada kaum wanita dan dia kurang berkenan dengan narasi Qur'an yg memberi tempat lebih kepada laki. Ini diperkuat oleh struktrur bahasa Arab yang memasukkan wanita dalam bahasa yang dipakai untuk lakilaki. Meski pertanyaan tersebut tidak mendapatkan penjelasan lebih rinci, namun belakangan para ahli tafsir sering menjadikan pertanyaan Ummu Salamah tersebut sebagai dasar argumen bahwa Qur'an menjadi satusatunya kitab yang berbicara langsung kepada kaum perempuan. (Asma Barlas, 2006: 255)

Meski begitu, meski pada beberapa ayat, qur'an bicara langsung kepada wanita, namun dalam beberapa hal unsur kesetaraan juga terdapat di dalamnya.

Contoh pada ayat 33:35 yang merinci secara tegas laki-laki dan wanita (muslim/muslimah, shalihin/shalihat), laki-laki dan perempuan yang sabar. Pada ayat ini Allah secara tegas berbicara tentang kedua pihak ini secara setara. Tafsiran serta pemahaman juga dibuat hampir senafas dengan ayat tersebut oleh para ulama, namun dalam perjalanannya, penafsiran hubungan lakilaki dan wanita tetap mengunggulkan laki-laki secara diskriminatif. Maka bisa dipahami, kendati qur'an bicara soal kesetaraan laki-laki dan wanita., namun dalam prakteknya itu tidak selalu terwujud dan menjadi awal bermula dari pertanyaan Ummu Salamah tersebut.

Patut juga diingat bahwa pertanyaan Ummu Salamah tersebut memantapkan kenyataan bahwa nilai kritis wanita diatara kaum mukminin bukan sekedar pelengkap, melainkan juga menjadikan wanita sebagai bagian dari wacana ketuhanan dan kemanusiaan. Pertanyaan Ummu Salamah juga menjelaskan bahwa jauh sebelum ide feminisme dan sejenisnya muncul. Pikiran wanita muslim terhadap aturan Ibahasa juga membuat mereka jadi lebih tajam dalam memandang posisi mereka di wilayah kehidupan.

Sayangnya, dalam mayoritas perjalanan sejarah, para wanita muslimah tidak mendapat kesempatan untuk mempertajam pertanyaan yang dibuat Ummu Salamah. Meski ada sejumlah muslimah lain yang menempati posisi sama dengan Ummu Salamah, seperti Aishah atau Khadijah, namun mereka tidak menampakkan pengaruh terkait dengan pertanyaan Ummu Salamah di awal tadi, kalaupun ada sifatnya pun sporadis dan tidak dalam satu tema soal posisi wanita.

Bukan hanya itu, masih pada waktu nabi hidup, sejumlah laki-laki berusaha mencari padanan setara yang menempatkan wanita dibawah standar yang telah disebut pada ayat terdahulu. Pemudaran pemahaman itu berlanjut secara bertahap ke beberapa abad berikut sampai pada tahap dimana pemikiran kesetaraan gender antara wanita dan laki-laki dalam qur'an sudah kehilangan "konotasi menyimpang." (Asma Barlas: 257)

Meski di pihak lain, ada sejumlah wanita dalam sejarah Islam yang menikmati kesetaraan tersebut. Contohnya dapat dilihat pada guru sufi Ibn Arabi yang dalam sejarahnya punya guru wanita. Hassan dan Al-Hibri (1880) menjadi orang pertama yang mencoba mengoreksi ketidaksetaraan tersebut khususya terkait dengan teks qur'an yang berkaitan dengan bacaan patriaki yang terdapat dalam Qur'an. Inti pemikiran Hassan berisikan kritik terhadap asumsi mendasar teologis yang menempatkan superioritas laki-laki. (Asma Barlas, 259)

Hasan menyitir sebagian keyakinan mayoritas muslim dalam hal itu, di antaranya adalah argumen bahwa Allah menciptakan lakilaki, bukan perempuan, sedangkan wanita tercipta dari tulang rusuk laki-laki. dengan demikian, wanita menenpati peran utama sebagai pusat kejatuhan laki-laki, bukan lakilaki itu sendiri, penyebab keluarnya Adam dari taman firdaus dll. Seluruh argument ini menurut Hassan salah. Hasan menyebutkan bahwa asal mula laki-laki dan wanita berasal dari satu unsur tunggal yakni nafas. Dalam Qur'an kata2 Adam dipakai sebanyak 21 kali dalam 25 kasus yang menjadi symbol dari "kesadaran 
kemanusian personal" yakni merupakan arti dari kata benda plural untuk kata "Kemanusiaan", bukan kata2 yang ditujukan kepada satu makhluk bernama laki-laki. (Asma B Asma Barlas, 260)

Pada akhirnya perbedaan pemahaman terhadap ayat-ayat al-Quran berdampak pada pemahaman dan penafsiran yang sinis terhadap kodrat dan peran wanita dalam ranah domestik, karena terkadang peran yang dilakukan wanita dalam rumah tangga dianggap sebagai kodrat yang harus dilakukan oleh para wanita tanpa kompromi. Padahal apa yang dipahami sebagai kodrat tersebut hanyalah pembagian kerja yang tidak berimbang antara laki-laki sebagai pencari nafkah dan perempuan yang notabanenya sebagai ibu rumah tangga. Hal tersebut seakan menular kepada pemahaman-pemahaman terhadap ayat-ayat lain yang berbicara mengenai kodrat perempuan, seperti menstruasi, mengandung (hamil) dan menyusui.

Dalam QS. Al-Baqarah/2: 222 dinyatakan:

tRqè=t «óio ur Ç’tã ÇÙ ÅsyJ ø9\$\# ( ö@è\% uqèd ] $r \&$ (\#qä9í tlôã\$\$sù uä!\$|ïiY9\$\# Îि ÇÙ ÅsyJ ø9\$\# ( wur f èdqç/t ø)s? 4Ó ®Lym tbö ßgôüt ( \#s î*sù tbö fgsüs? ÆE èdqè?ù'sù ô 'ïB ß]ø ym ãNä.t tBr\& a !\$\# 4 "bî) @!\$\# $=$ lit ä $\mathrm{t}$ ûüÎ $/$ o§q-G9\$\# =ït ä ur
úìi ÎdgsÜtFßJ ø9\$\# ÇËËËÈ

Berikut adalah terjemahan Departemen Agama "Mereka bertanya kepada kamu tentang haid. Katakanlah haid itu adalah kotoran...". Kata al-mahid (orang yang menstruasi), diartikan dengan haid (menstruasi) yang dinyatakan Allah sebagai aza (kotoran). Dalam menafsirkan ayat tersebut, Zaitunah Subhan tidak sependapat dengan terjemahan al-Quran Departemen Agama yang menerjemahkan kata azza sebagai kotoran, sebagaimana juga dalam tafsir Hamka dan Mahmud Yunus.--- Lihat penafsiran tentang hal ini versi Al Qur'an dan Tafsirnya Departemen Agama, Tafsir al Qur'an al Karim Mahmud Yunus, dan Tafsir al Azhar
Hamka.--- Menurutnya kotoran adalah suatu yang menjijikkan dan harus dijauhi, sedangkan haid merupakan pemberian dari Tuhan kepada perempuan yang merupakan kodratnya. Wanita dalam keadaan menstruasi hendaknya dipahami untuk tidak bersetubuh, dan hal ini adalah karena halangan bukan karena kotoran.

Dari beberapa terjemahan kata di atas, penulis memahami bahwa kata al mahīdl dalam ayat ini lebih tepat diartikan dengan " tempat keluar haidl". Bukan haidlnya itu sendiri, karena Tuhan menggunakan kata al Mahīdl bukan haidl. Walaupun kedua kata tersebut sama-sama dalam bentuk mashdlarl verbal tetapi kata yang pertama menekankan "tempat" haidl (maudli' al haidl) sedangkan yang kedua menekankan "waktu "dan "zat haidl" (Nasharudin Umar, 2003: 176)

Dalam ayat-ayat al-Quran yang terkait atau sesuai dengan perempuan seperti dalam surat al-Baqarah/2:196 yang berarti sakit atau gangguan, QS. Al-Baqarah/2: 262 dan 263 yang berarti menyakitkan, QS. Ali Imran/ 3: 111 dan 186, QS. Al-Ahzab/33: 48 yang berarti gangguan serta dalam QS. Al-Nisa'/4: 102 yang artinya kesusahan.

Setelah melihat beberapa ayat yang berbicara mengenai kata kunci tersebut yaitu $a z a$, maka perlu menguraikan latar belakang turunnya ayat (asbab nuzul) dari ayat yang dibahas. Terkait dengan ayat menstruasi, dijelaskan bahwa ayat ini turun dalam konteks kebiasaan orang-orang Yahudi di Madinah yang bertetangga dengan orang-orang muslim. Mereka mempunyai peraturan terhadap wanitawanita yang sedang menstruasi sebagaimana yang tersebut di dalam Perjanjian Lama kitab Imamat orang Lewi pasal 15: 19-24 yang berbunyi bahwa wanita menstruasi harus mengasingkan diri, dan segala yang disentuh atau diduduki menjadi najis. Karena aturan ini, maka para suami tidak mau bersama dengan istri yang sedang menstruasi. Bahkan mereka tidak mau makan dan minum bersama, dan tidak tinggal serumah sepanjang masa menstruasi tersebut. Hingga pada suatu hari para sahabat bertanya mengenai kebenarannya.

Berdasarkan penelusuran di atas, bahwa orang-orang Yahudi memberikan tempat bagi wanita yang sedang menstruasi terpisah selama 
tujuh hari dan siapa pun yang menyentuh akan ternoda dan najis, tidak diperbolehkan tinggal serumah, tidak boleh makan dan minum, bahkan tidur bersama. Sedangkan orang-orang Nasrani, bergaul seperti biasa dengan wanita haid, mereka tidak membedakan bagi wanita yang sedang haid dan menggaulinya secara bebas serta berbuat sesuka hati mereka. Inilah konteks sosial yang melatari turunnya ayat mengenai menstruasi pada wanita. (Zaitunah Subhan, 26).

Sahabat Anas bin Malik meriwayatkan, Rasulullah SAW bersabda, "Segala sesuatu boleh kamu perbuat dengan istrimu yang sedang menstruasi selain bersetubuh". Bahkan Rasulullah dalam banyak kesempatan menegaskan kebolehan melakukan kontak sosial dengan wanita haid. "Segala sesuatu boleh untuknya kecuali bersetubuh (al jima')". Bahkan Rasulullah seringkali mengamalkan kebolehan itu dalam bentuk praktek. Riwayat lain secara demonstratif disampaikan 'Aisyah, antara lain, " "Aisyah pernah minum dalam satu bejana yang sama dengan Rasulullah ketika dalam keadaan haidl, juga pernah menceritakan Rasulullah melakukan segala sesuatu selain bersetubuh (al jima') sementara dirinya dalam keadaan haid, juga Rasulullah sama sekali tidak memperlihatkan perlakuan taboo terhadap darah ahid dan bekasnya yang terdapat dalam pakaian 'Aisyah. (Nasaruddin Umar, 176)

Pada penjelasan di atas dapat dipahami bahwa ayat yang berisi tentang larangan bagi suami untuk mendekati istrinya ketika sedang dalam keadaan "berhalangan". Hal ini berisi isyarat untuk menjaga kesehatan perempuan agar terlindung dari penyakit yang timbul akibat hubungan sex yang dilakukan ketika perempuannya dalam keadaan berhalangan. Semuanya itu untuk melindungi perempuan tersebut.

Walaupun secara normatif, al-Quran dan
Sunnah terkesan mendorong semangat kemitraan atau kesejajaran antara laki-laki dan wanita. Tetapi secara kontekstual al-Quran menyatakan adanya kelebihan tertentu bagi kaum pria atas wanita, sebagaimana termaktub dalam QS. Al-Nisa: 43, mengenai status suami sebagai qawwamun bagi kaum wanita. Begitu pula dengan ayat yang menjelaskan proses penciptaan Adam dan Hawa dalam beberapa ayat Quran, seperti QS. Al-Nisa: 1, QS. Al-Rum: 21, QS. Al-A'raf: 189, dan pada beberapa ayat Quran lainnya. Ayat-ayat tersebut menimbulkan interpretasi terhadap wanita dan menempatkan kaum pria pada superioritas.

Di sisi lain, dalam penafsiran ayat yang berkaitan dengan perempuan sangat banyak dipengaruhi oleh cerita-cerita israiliyat. Bisa jadi penafsiran tersebut terkontaminasi dengan penganut Yahudi dan Nashrani yang masuk Islam, atau memang sengaja berupa penyusupan ke dalam tradisi pengajaran Islam. Oleh sebab itu perlu dikaji ulang penafsiran yang mendeskriditkan peran perempuan dengan merekonstruksi tafsir dengan menggunakan metode yang lebih mendekati maksud dan tujuan diturunkan ayat tersebut. Perlu pula dicermati justifikasi yang berasal dari al-Qur'an maupun hadis, apakah memang itu yang dimaksud atau lebih dan masih ada kaitan dengan ayat lain atau nash lain. Bisa jadi pendapat mufassir masa lalu itu ada benarnya, namun mereka sangat terkondisikan oleh ruang dan waktu serta pengetahuan mereka atas keabsahan riwayat israiliyyat.

Pada teks al Kitab secara eksplisit termaktub sehingga terlihat pada diskriminasi dengan pencitraan yang sulit dirubah dalam tradisi masyarakat. Anggapan bahwa perempuan sebagai penggoda dapat dijumpai dalam teks Kitab Kejadian 3: 12: "Manusia: " Perempuan yang Kau tempatkan disisiku, dialah yang memberi dari buah pohon itu kepadaku, maka kumakan". Sebagai sanksi terhadap kesalahan perempuan itu maka kepadanya dijatuhkan semacam sanksi sebagaimana disebutkan dalam Kitab Kejadian 3: 16: " FirmanNya kepada perempuan itu: Susah payahmu waktu mengandung akan kubuat sangat banyak; dengan kesakitan engkau akan melahirkan anakmu; namun engkau akan berahi kepada suamimu dan ia akan berkuasa atasmu". Oleh sebab itu disebutkan bahwa akibat pelanggaran dari Hawa/Eva di surga maka kaum perempuan secara keseluruhan akan menanggung sepuluh (10) beban penderitaan. Antara lain : prihal akan mengalami siklus menstruasi yang sebelumnya tidak pernah dialami Hawa. Jadi menstruasi yang dialami perempuan bukanlan kodrat yang ada pada diri perempuan tersebut melainkan 
akibat dari kesalahan --- nenek moyang manusia yang memakan buah terlarang---.

Hal ini berbeda dengan al Qur'an bahwa wanita haidh atau menstruasi merupakan kodratnya sebagai wanita dan memandang lebih positif terhadap manusia. Al Qur'an menegaskan bahwa Allah swt memuliakan seluruh anak cucu Adam, tanpa membedakan jenis kelaminnya dan warna kulit. Bahkan tidak pernah ada ditemukan satu ayat pun yang menunjukkan keutamaan seseorang karena faktor jenis kelamin atau karena keturunan suku bangsa tertentu.

\section{SIMPULAN}

Pada teks kitab suci mengakui ada perbedaan secara biologis di antara perempuan dan laki-laki, namun perbedaan itu bukan dimaksudkan agar untuk mengistimewakan yang satu dan menghinakan yang lain. Perbedaan itu dimaksudkan agar perempuan dan laki-laki melengkapi satu dengan yang lain sehingga keduanya dapat hidup bersama dalam damai dan harmoni, saling mengasihi, saling mencintai dan saling menghormati. Nilai kemanusiaan laki-laki dan perempuan adalah sama. Di hadapan Tuhan, perbedaan di antara manusia hanya terletak pada kualitas taqwanya--dalam al qur'an--, bukan pada jenis jendernya. Karena itu, agama -- dalam hal ini pada teks kitab suci-- mengutuk semua bentuk diskriminasi jender.

\section{DAFTAR RUJUKAN}

Arkoun, Mohammed. 1999. Membongkar Wacana Hegemonik (Dalam Islam dan Post Modernisme), Min Faish al Tafriqah ila Fashl al Maqal Ain al Fikr al Islam al Muassr. Surabaya: AlFikr.

Bhasin, Kamla. 2001. Understanding Gender, terj. Moh. Zaki Hussein, Jakarta: TePLOK Press.

Conolly, Peter. Aneka Pendekatan Studi Agama (Terjemahan). Imam Khoiri. Yogyakarta: LkiS, 2009.

Departemen Agama RI. 1998. Al Qur'an dan Terjemahannya. Semarang, Toha Putera.
Elias, Anthon Elias. 1977. Modern Dictionary Arabic-English. Kairo: al-Nahdlah alJadid.

Freyer, Barbara. 1994. Reinterpretasi Jender (Wanita dalam Al Qur'an, Hadis dan Tafsir). Bandung. Pustaka Hidayah.

Glasse, Cyril. 1999. Ensiklopedi Islam (Ringkas). Jakarta, Raja Grafindo.

Hasan, Hamka. 2009. Tafsir Jender (Studi Perbandingan Antara Tokoh Indonesia dan Mesir). Jakarta: Balitbang dan Dikti Depag RI.

Humm, Maggie. 2002. Ensiklopedia Feminisme, terj. Mundi Rahayu. Yogyakarta: Fajar Pustaka Baru.

Jamil, Asriati dan Amany Lubis. 2003. Seks dan Gender dalam Pengantar Kajian Gender . Jakarta: PSW Press.

Khan, Wahiduddin, 2001. Antara Islam dan Barat (Perempuan di tengah Pergumulan) Terjemahan: Abdullah Ali, Woman Betwewn Islam and Western Society. Jakarta: Serambi Ilmu Semesta.

Mas'ud, Jurjan, al-Ra'idu. 1981. Mu'jam Lughawy al-'Asry. Beirut: Dar al-Ilm.

Musdah Mulia, Siti. 2007. Islam \& Inspirasi Jender. Yogyakarta: Kibar Press.

Mc Auliffe, Jane Dammen (Ed). 2006. The Cambridge Companion to The Qur'an. UK. Cambridge University Press.

Nadjib, Ala'iy, 2005. Perempuan dan Pluralisme, dalam Nilai-nilai Pluralisme Dalam Islam (Bingkai Gagasan Yang Berserak), Sururin (ed). Bandung: Nuansa.

Qardawy, Yusuf, 1998. al Madkhal li al Dirasah al Sunnah al Nabawiyyah, Kairo: Maktabah Wahbah, 1998.

Siddique, Kaukah. 2002. Menggugat Tuhan yang Maskulin. Jakarta: Paramadina.

Spickard, James V, 2006. Hak Asasi Manusia, Konflik-konflik Religius, dan Globalisasi: Nilai-nilai Puncak di sebuah Tatanan Baru, (Artikel) Jurnal al-Huda.

Subhan, Zaitunah. 1999. Tafsir Kebencian: Studi Bias Gender dalam Tafsir Qur'an. Yogyakarta: LKIS. 
Sururin (Ed). 2005. Nilai-nilai Pluralisme Dalam Islam. Bandung: Nuansa.

Umar, Nasaruddin. 2001. Argumen Kesetaraan Jender; Perspektif al-Quran. Jakarta Selatan: Paramadina. 2003. Teologi Jender (Antara Mitos dan Teks Kitab Suci). Jakarta: Pustaka Cicero,

Thameem Ushama. 2000. Metodologi Tafsir alQur'an Kajian Kritis, Objektif dan Komprehensif. Jakarta: Riora Cipta, 2000.

Bagir, Haidar. 2005. Kisah-kisah Pembawa Berkah. Jakarta: Yasmin.

Rahmat, Jalaluddin. 1999. Islam Aktual (Refleksi-Sosial Seorang Cendekiawan Muslim). Bandung: Mizan.
Rahman, Fazlur. 1996. Tema Pokok al-Qur'an, terj, Anas Mahyudin. Bandung: Pustaka.

Wahid, Abdurrahman. 2006. Islamku, Islam Anda, Islam Kita (Agama Masyarakat Negara Demokrasi). Jakarta: The Wahid Institut.

Al-Zarqaniy, Muammad Abd Adzim. tth. Manahil al-Irfan fi ulum al-Qur'an. Mesir: Mustafa al-Bab al-Halabi. 